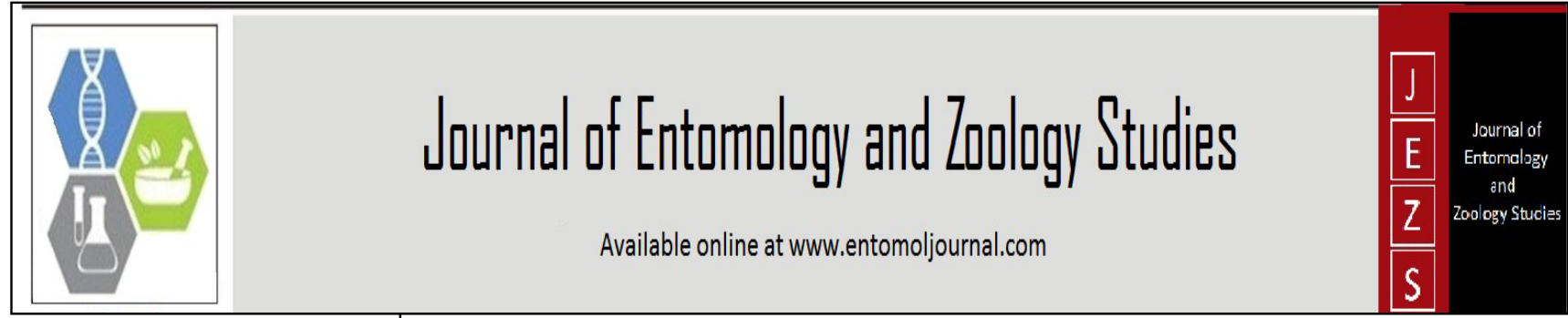

E-ISSN: 2320-7078 P-ISSN: 2349-6800 JEZS 2016; 4(1): 487-490

(C) 2016 JEZS

Received: 26-11-2015

Accepted: 28-12-2015

Mark Ian Cooper

Department of Biological

Sciences, Private Bag X3,

University of Cape Town,

Rondebosch 7701, South Africa.

Correspondence

Mark Ian Cooper

Department of Biological

Sciences, Private Bag X3,

University of Cape Town,

Rondebosch 7701, South Africa.

\section{Instantaneous insemination in the millipede Centrobolus inscriptus (Spirobolida: Trigoniulidae) determined by artificially-terminated mating}

\section{Mark Ian Cooper}

\section{Abstract}

Male millipedes may control the duration of copulation and maintain genital contact with females in relation to the intensity of sperm competition. Post-insemination associations were considered in arthropods and the timing of insemination in the millipede Centrobolus inscriptus calculated by artificially-terminated radiolabelled mating. Copula pairs were separated after 1, 2, 3, 4, 5, 10, 20, and 30 minutes of copulation. Ejaculate volumes inseminated did not correlate significantly with the manipulated copulation durations $(\mathrm{r}=-0.35 \mathrm{df}=8, \mathrm{P}=0.35)$. High $(c a .2500 \mathrm{dpm})$ and low values in the first 5 minutes evidenced "instantaneous-insemination" and self-sperm displacement. Instantaneous insemination was demonstrated using artificially terminated mating in Centrobolus inscriptus by showing no relationship between ejaculate volume and copulation duration except for the high and low volumes at the beginning of mating when the male loads and seats the gonopods before adaptive mate-guarding by prolonged copulation.

Keywords: Arthropoda; Centrobolus inscriptus; Diplopoda; postinsemination; mate-guarding

\section{Introduction}

Mate guarding is known in the Arthropod classes Diplopoda [1-14, 58-59]; Araneae ${ }^{\text {[44, 47-48] }}$; Acari [45-46, 61, 65]; Crustacea [49-50, 56-57, 60, 62]; Scorpiones [52]; Opiliones [53]; and Insecta, orders Orthoptera $^{[31,51]}$, Odonata ${ }^{[26,34,35]}$, Phasmida ${ }^{[36]}$, Lepidoptera ${ }^{[21,37]}$, Diptera ${ }^{[30,38]}$, Coleoptera [19, 20, 22, 27, 29, 39, 40, 63-64], Hymenoptera [28, 41], Hemiptera [15-18, 23-25, 42-43]. Post-insemination associations and the mate-guarding hypothesis has been previously reviewed for Insecta ${ }^{[32]}$. Millipedes (Class: Diplopoda) have highly polygynandrous mating systems that are very complex because males and females can mate multiply and prolong copulations with maintained genital contact where males control the duration of copulation and maintain genital contact with females in relation to the intensity of sperm competition ${ }^{[1-4]}$. The instantaneous timing of insemination has been detected using radiolabeled ejaculates in Alloporus uncinatus (Spirostreptida: Sprirostreptidae), followed by the adaptive mate-guarding phase with maintained genital contact ${ }^{[13]}$. The collection of sperm at the bottom of the spermathecae from the beginning of insemination with time after the start of copulation indicated prolonged copulation was the adaptive mate-guarding phase ${ }^{[13]}$. The objective of the present study is to determine the timing of insemination in the millipede Centrobolus inscriptus, replicating the artificially-terminated radio-labelled mating experiments which were performed in $A$. uncinatus $^{[13]}$, to test if prolonged genital contact is the adaptive mate-guarding phase.

\section{Materials and Methods}

Millipedes were hand collected (1996-1998) from indigenous coastal forest at Twin Streams Farm, Mtunzini, South Africa $\left(28^{\circ} 55^{\prime} \mathrm{S}, 31^{\circ} 45^{\prime} \mathrm{E}\right)$. Live specimens of each sex were transported to Cape Town and kept at $25^{\circ} \mathrm{C}$ temperature; $70 \%$ relative humidity; $12: 12$ hours light-dark cycle. Food was provided in the form of fresh vegetables ad libitum. Unisex groups were housed in plastic containers containing moist vermiculite $( \pm 5 \mathrm{~cm}$ deep) before the mating experiments commenced. The radioisotope labelling technique allowed two types of ejaculates to be discerned ${ }^{[11]}$. A Hamilton syringe was used to inject $50 \mathrm{uL}$ aliquots of tritiated [methyl] thymidine (85 Ci I mmol, Amersham, UK) between the tergites of the 10th and 11th diplosegments of individual males (L). A second class of males did not receive the treatment and were left unlabelled males (UL). Females were killed in ethyl-acetate jars after their last copulation and the paired sperm storage organs were dissected out under a magnifying lens 
(5X). Left and right spermathecae were placed in separate $7 \mathrm{ml}$ scintillation vials and vortexed for $30 \mathrm{~s}$ with $0.1 \mathrm{ml}$ concentrated $\mathrm{HCl}$ to promote rapid tissue homogenisation ${ }^{[12]}$. Acid was neutralised with $0.1 \mathrm{ml} 5 \mathrm{M} \mathrm{NaOH}$ prior to adding 3.5 $\mathrm{ml}$ scintillation fluid (Scintillator 299, Packford). The volume of labelled ejaculate present in the female spermathecae was quantified in disintegrations per minute (dpm) of radioisotope using a 1600 scintillation counter (low count reject $=0$; dpm multiplier $=1$ ). Thus dpm values were used as volumetric indications of the labelled ejaculate present in the female spermathecae. Radiolabelled males were used in artificiallyterminated matings to elucidate the timing of insemination ${ }^{[12]}$. Copula pairs were separated after 1, 2, 3, 4, 5, 10, 20, and 30 minutes of copulation. Statistical analyses were performed using Statgraphics (version 6.0). The non-parametric nature of disintegration counts ${ }^{[11]}$, coupled with small sample sizes, did not allow data to be normally transformed. Pearson's correlation coefficients were used to analyse the relationships between ejaculate volume, copulation time and body mass.

\section{Results}

Ejaculate volumes (Figure 1) inseminated did not correlate significantly with the manipulated copulation durations $(\mathrm{r}=$ 0.35 , $\mathrm{df}=8, \mathrm{P}=0.35$ ) but the first few data points indicate very high volumes (ca. $2500 \mathrm{dpm}$ ) deposited within the first five minutes interspersed with the range of lower volumes. Male body mass was not related to ejaculate volume $(r=0.54$, $\mathrm{df}=8, \mathrm{p}=0.13)$ and was not related to copulation duration ( $\mathrm{r}$ $=-0.64, \mathrm{df}=8, \mathrm{P}=0.06$ ).

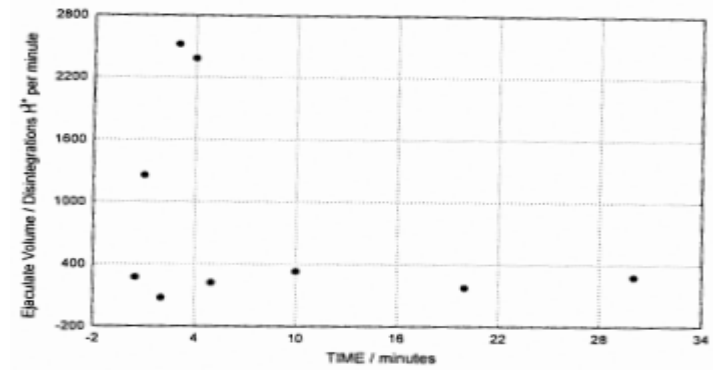

Fig 1: The ejaculate volumes inseminated by radiolabelled males of Centrobolus inscriptus when matings were terminated at different stages.

\section{Discussion}

The lack of correlation between ejaculate volume inseminated and manipulated copulation duration evidenced "instantaneous-insemination" during which time the male loads and seats the gonopods before engaging in the adaptive mate-guarding phase ${ }^{[12]}$. This was supported by high and low volumes of ejaculate in the first five minutes of copulation supporting self-sperm displacement and matches the predicted results found in the spirostreptid $A$. uncinatus ${ }^{[13]}$. The absence of an allometric relationship here supports the previous findings in millipedes. This is an interesting result and probably indicates this is the situation in all Julid millipedes where there is a post-insemination association. It was critical to discern between the different stages or phases of copulation in order to show mate-guarding as an adaptation to counter sperm-competition through the integration of pre- or syncopulatory and post-copulatory events ${ }^{[33]}$.

\section{Conclusion}

Instantaneous insemination was demonstrated using artificially terminated mating in Centrobolus inscriptus by showing no relationship between ejaculate volume and copulation duration except for high and low volumes at the beginning of mating when the male loads and seats the gonopods before adaptive mate-guarding by prolonged copulation.

\section{Acknowledgements}

Susan Mvungi and Junaid Lucas provided a digital copy of the Author's thesis. Mandy Barnett provided laboratory assistance.

\section{References}

1. Telford SR, Dangerfield JM. Sex in millipedes: laboratory studies on sexual selection. Journal of Biological Education. 1990; 24(4):233-238.

2. Telford SR, Dangerfield JM. Manipulation of the sex-ratio and duration of copulation in the tropical millipede Alloporus uncinatus - a test of the copulatory guarding hypothesis. Animal Behaviour 1990; 40(5):984-986.

3. Telford SR, Dangerfield JM. Mating tactics in the tropical millipede Alloporus uncinatus (Diplopoda: Spirostreptidae). Behaviour 1993; 124(1):45-56.

4. Telford SR, Dangerfield JM. Males control the duration of copulation in the tropical millipede Alloporus uncinatus (Diplopoda: Julida). South African Journal of Zoology. 1994; 29(4):266-268.

5. Telford SR, Dangerfield JM. Sexual selection in savanna millipedes: Products, patterns and processes. In: Geoffroy, J. J., Mauries, J.P. \& Nguyen Duy-Jacquemin, Mémoires du Muséum National d'Histoire Naturelle 1996; 169:565576.

6. Telford SR, Dangerfield JM. Males control the duration of copulation in the tropical millipede Alloporus uncinatus (Diplopoda: Julida). South African Journal of Zoology 1994; 29(4):266-268.

7. Barnett M, Telford SR, Villiers de CJ. The genital morphology of the millipede Orthoporus pyrhocephalus (Diplopoda: Spirostreptidae) - a possible mechanism of sperm displacement. Proceedings of the Electron Microscopy Society of South Africa 1991; 21:15-17.

8. Cooper MI, Telford SR. Copulatory sequences and sexual struggles in millipedes. Journal of Insect Behaviour. 13(2):217-230.

9. Barnett M, Telford SR, Villiers de CJ. Sperm competition in a millipede? An investigation into the genital morphology of the southern African spirostreptid millipede Orthoporus pyrrocephalus. Journal of Zoology London. 1993; 231(3):511-522.

10. Barnett M, Telford SR. Sperm competition and the evolution of millipede genitalia. In JC Geoffroy, JP Mauries, M Nguyen Duy-Jacquemin. Mémoires du Muséum National d'Histoire Naturelle 1996; 169:331-339.

11. Barnett M, Telford SR, Tibbles BJ. Female mediation of sperm competition in the millipede Alloporus uncinatus (Diplopoda: Spirostreptidae). Behavioural Ecology and Sociobiology 1995; 36(6):413-419.

12. Barnett M, Telford SR. The timing of insemination and its implications for sperm competition in a millipede with prolonged copulation. Animal Behaviour 1994; 48(2):482484. 
13. Rowe M. Copulation, mating system and sexual dimorphism in an Australian millipede, Cladethosoma clarum. Australian Journal of Zoology. 2010; 58(2):127132.

14. Galipaud M, Bollache L, Dechaume-Moncharmont F-X. Assortative mating by size without a size-based preference: the female-sooner norm as a mate-guarding criterion. Animal Behaviour 2013; 85(1):35-41.

15. Sillén-Tullberg B. Prolonged copulation: A male 'postcopulatory' strategy in a promiscuous species, Lygaeus equestris (L.) (Heteroptera: Lygaeidae). Behavioural Ecology and Sociobiology 1981; 9(4):283289.

16. Clark SJ. The effects of operational sex-ratio and fooddeprivation on copulation duration in the water strider (Gerris-remigis Say). Behavioural Ecology and Sociobiology 1988; 23(5):317-322.

17. Campbell V, Fairbairn DJ. Prolonged copulation and the internal dynamics of sperm transfer in the water strider Aquarius remigis. Canadian Journal of Zoology 2001; 79(10):1801-1812.

18. McLain DK. Prolonged copulation as a post-insemination guarding tactic in a natural population of the ragwort seed bug. Animal Behaviour 1989; 38(4):659-664.

19. Harano K, Tanaka S, Yasui H, Wakamura S, Nagayama A, Hokama $\mathrm{Y}$ et al. Multiple mating, prolonged copulation and male substance in a scarab beetle Dasylepida ishigakiensis (Coleoptera: Scarabaeidae). International Journal of Tropical Insect Science 2010; 30(3):119-126.

20. Wing SR. Prolonged copulation in Photinus macdermotti with comparative notes on Photinus collustrans (Coleoptera: Lampyridae). The Florida Entomologist 1985; 68(4):627-634.

21. Watanabe M, Nakanishi Y, Bonno M. Prolonged copulation and spermatophore size ejaculated in the sulfur butterfly, Colias erate (Lepidoptera: Pieridae) under selective harassments of mated pairs by conspecific lone males. Journal of Ethology. 1997; 15(1):45-54.

22. Harari AR, Landolt PJ, O’Brien CW, Brockmann HJ. Prolonged mate guarding and sperm competition in the weevil Diaprepes abbreviates (L.). Behavioural Ecology, 14(1):89-96.

23. Schöfl G, Taborsky M. Prolonged tandem formation in firebugs (Pyrrhocoris apterus) serves mate-guarding. Behavioural Ecology and Sociobiology 2002; 52(5):426433.

24. Carroll SP. The adaptive significance of mate guarding in the soapberry bug, Jadera haematoloma (Hemiptera: Rhopalidae). Journal of Insect Behaviour 1991; Journal of Insect Behaviour 1991; 4(4):509-530.

25. Vitta ACR, Lorenzo MG. Copulation and mate guarding behavior in Triatoma brasiliensis (Hemiptera: Reduviidae). Journal of Medical Entomology. 2009; 46(4):789-795.

26. Andres JA, Rivera AC. Copulation duration and fertilization success in a damselfly: an example of cryptic female choice? Animal Behaviour 2000; 59(4):696-703.

27. Saeki Y, Kruse KC, Switzer PV. Physiological costs of mate guarding in the Japanese beetle (Popillia japonica Newman). Ethology 2005; 111(9):863-867.
28. Brown MJF, Baer B. The evolutionary significance of long copulation duration in bumble bees. Apidologie, 36(2):157-167.

29. Chaudhary DD, Mishra G, Omkar O. Prolonged matings in a ladybird, Menochilus sexmaculatus: A mate guarding mechanism? Journal of Asia-Pacific Entomology, 18(3): 453-458.

30. Martin OY, Hosken DJ. Strategic ejaculation in the common dung fly Sepsis cynipsea. Animal Behaviour 2002; 63(3):541-546.

31. Parker GA, Smith JL. Sperm competition and the evolution of the precopulatory passive phase in Locusta migratoria migratorioides. Physiological Entomology 1975; 49(2):155-171.

32. Alcock J. Postinsemination associations between males and females in Insects: The mate-guarding hypothesis. Annual Review of Entomology 1994; 39(1):1-21.

33. Parker GA, Pizzari T. Sperm competition and ejaculate economics. Biological Reviews 2010; 85(4):897-834.

34. Cordero A. The adaptive significance of prolonged copulations of the damselfly, Ischnura graellsii (Odonata: Coenagrionidae). Animal Behaviour 1990; 40(1):43-48.

35. Michiels NK. Consequences and adaptive significance of variation in copulation duration in the dragonfly Sympetrum danae. Behavioural Ecology and Sociobiology 1992; 29(6):429-435.

36. Sivinski J. Predation and sperm competition in the evolution of coupling durations, particularly in the stick insect Diapheromera veliei. In Competition in a diverse group of Insects, Gwynne DT, Morris GK, Westview, USA, 1983, 147-162.

37. Drummond BA III. Multiple mating and sperm competition in the Lepidoptera. In Smith RL, Sperm competition and the evolution of Insect mating systems, Academic Press, New York, 1984, 291-370.

38. Thornhill R. Sexual selection within mating swarms of the lovebug Plecia nearctica (Diptera: Bibionidae). Animal Behaviour 1980; 28(2): 405-412.

39. Peschke K. Male aggression, female mimicry and female choice in the rove beetle, Aleochara curtula. Ethology 1987; 75(4):265-284.

40. Snead S, Alcock J. Aggregation formation and assortative mating in two meloid beetles. Evolution 1985; 39(5):1123-1131.

41. Rutowski R, Alcock J. Temporal variation in male copulatory behaviour in the solitary bee Nomadopsis puellae (Hymenoptera: Andrenidae). Behaviour 1980; 73(3/4):175-188.

42. Carroll SP, Loye JE. Male-biased sex ratios, female promiscuity, and copulatory mate guarding in an aggregating tropical bug, Dysdercus bimaculatus. Journal of Insect Behaviour. 1990; 3:33-48.

43. McLain DK. Female choice and adaptive significance of prolonged copulation in Nezara viridula (Hemiptera: Pentatomidae). Psyche 1980; 87(3-4):325-336.

44. Sziranyi A, Kiss B, Samu F. The function of long copulation in the wolf spider Pardosa agrestis (Araneae, Lycosidae) investigated in a controlled copulation duration experiment. The Journal of Arachnology. 2005; 33:408-414. 
45. Radwan J. Sperm competition in the mite Caloglyphus berlesei. Behavioural Ecology and Sociobiology 1991; 29(4):291-296.

46. Radwan J, Siva-Jothy MT. The function of postinsemination mate association in the bulb mite, Rhizoglyphus robini. Animal Behaviour 1996; 52(4):651657.

47. Elgar MA, Bathgate R. Female receptivity and male mateguarding in the jewel spider Gasteracantha minax Thorell (Araneidae). Journal of Insect Behaviour. 1996; 9(5):729738.

48. Calbacho-Rosa L, Peretti AV. Copulatory and postcopulatory sexual selection in Haplogyne spiders, with emphasis on Pholcidae and Oonopidae. In Peretti AV, Aisenberg A, Cryptic female choice in Arthropods, Springer, Switzerland, 2015, 109-144.

49. Elgar MA. Sperm competition and sexual selection in spiders and other Arachnids. In Birkhead TR, Møller, AP, Sperm competition and sexual selection. Academic Press, New York, 1998, 307-339.

50. Jivoff $P$. The relative roles of predation and sperm competition on the duration of the post-copulatory association between the sexes in the blue crab, Callinectes sapidus. Behavioural Ecology and Sociobiology 1997; 40(3):175-185.

51. Jivoff P, Hines AH. Female behaviour, sexual competition and mate guarding in the blue crab, Callinectes sapidus. Animal Behaviour 1998; 55(3):589-603.

52. Tuni C, Beveridge M, Simmons LW. Female crickets assess relatedness during mate guarding and bias storage of sperm towards unrelated males. Journal of Evolutionary Biology. 2013; 26(6):1261-1268.

53. Benton TG. Determinants of male-mating success in a scorpion. Animal Behaviour 1992; 43(1):125-135.

54. Buzatto BA, Machado G. Male dimorphism and alternative reproductive tactics in harvestmen (Arachnida: Opiliones). Behavioural Processes 2014; 109(A):2-13.

55. Machado G, Requena GS, Toscano-Gadea C, Stanley E, Macías-Ordóñez R. Male and female mate choice in Harvestmen: General patterns and inferences on the underlying processes. In Peretti AV, Aisenberg A, Cryptic female choice in Arthropods, Springer, Switzerland, 2015, 169-201.

56. Jormalainen V, Merilaita S. Female resistance and duration of mate-guarding in three aquatic peracarids (Crustacea). Behavioral Ecology and Sociobiology 1995; 36(1):43-48.

57. Benvenuto C, Knott B, Weeks SC. Mate-guarding behavior in clam shrimp: a field approach. Behavioural Ecology 2009; 20(6):1125-1132.

58. Adolph SC, Geber MA. Mate-guarding, mating success and body size in the tropical millipede Nyssodesmus python (Peters) (Polydesmida, Platyrhacidae). Southwestern Naturalist 1995; 40(1):56-61.

59. Heisler IL. Nyssodesmus python. In Costa Rican Natural History, Janzen DH, University of Chicago Press, Chicago, 1983, xi +816 .

60. Glatzel T, Schminke HK. Mating behaviour of the groundwater copepod Parastenocaris phyllura Kiefer, (Copepoda: Harpacticoida). Contributions to Zoology 1938; 66(2):103-108.
61. Fashing NJ. Mate-guarding in the genus Creutzeria (Astigmata: Histiostomatidae), an aquatic mite genus inhabiting the fluid-filled pitchers of Nepenthes plants (Nepentheaceae). Systematic \& Applied Acarology 2008; 13(3):163-171.

62. Goshimaa S, Kogab T, Muraib M. Mate acceptance and guarding by male fiddler crabs Uca tetragonon (Herbst). Journal of Experimental Marine Biology and Ecology. 1996; 196(1-2):131-143.

63. Sato H, Hiramatsu K. Mating behaviour and sexual selection in the African ball-rolling scarab Khepher platynotus (Bates) (Coleoptera: Scarabaeidae). Journal of Natural History. 1993; 27(3):657-668.

64. Knox TT, Scott MP. Size, operational sex ratio, and mateguarding success of the carrion beetle, Necrophila Americana. Behavioural Ecology 2006; 17(1):88-96.

65. Oku K. Sexual selection and mating behavior in spider mites of the genus Tetranychus (Acari: Tetranychidae). Applied Entomology and Zoology 2014; 49(1):1-9. 